\title{
The Influence of the Dividend Payout Ratio (Dpr) and the Current Ratio (Cr) Against the Growth of Share Prices in the Service Sector Companies the Period 2011 - 215, in Indonesia
}

\author{
Hais Dama \\ Doctoral candidate of Economics University of Indonesia Muslim (UMI) in Makassar \\ Masdar Mas'ud \\ Professor programs Economics University of Indonesia Muslim \\ Lukman Chalid \\ Co Promoter, Program Economics University of Indonesia Muslim \\ St. Sukmawati \\ Co Promoter, Program Economics University of Indonesia Muslim
}

\begin{abstract}
The title, the influence of the Dividend Payout Ratio and Curren Ratio against the establishment of the share price on the service sector company perikde 20122 - 2015. This research aims to find out if the Current Ratio and Dividend Payout Ratio effect on the growth of service sector Companies stock prices listed on the Indonesia stock exchange. This research data obtained by downloading annual report through the official website so that the data in this study is secondary data. The research method used is the method of quantitative deskriftif by using the application's e-viws of doing data processing, source data taken from Bursa Efefk Indonesia through the website. Research results show that the positive influence and significant dividend payout ratio against share price growth as evidenced by the value of the $t$-count is greater than the t-table. While the Current ratio of influential negatife against the growth of the share price. The simultaneous influence of the dividend payout ratio and curren ratio together more influenced positively and significantly to the growth of prices of shares with a value of determination of $75.05 \%$.
\end{abstract}

Keywords:- Current Ratio (CR), Dividend Payout Ratio (DPR), the growth of share prices of.

\section{INTRODUCTION}

The capital market as well as the traditional market in which there is a buyer and seller to Transact deals price, the difference only lies in the reproduced instruments are traded, which reproduced instruments traded in capital market instruments, namely the ownership (stocks) and long-term debt (bonds). Shareholders (investors) have the authority in deciding will purchase, retain, sell or increase the number of shares, any change in a wide range of micro and macro economic condition will join in encouraging the formation of a variety of conditions that requires an investor to decide what to do and what strategy is applied in order to obtain a fixed return is expected.

Dividend Payout Ratio is an indication of the top percentage of the amount of income earned, which is distributed to owners or shareholders in the form of cash.
Dividend Payout Ratio is determined the company to pay a dividend to shareholders every year, the determination of the Dividend Payout Ratio based on his little big profit after tax, are generally dividends paid to shareholders in cash (cash dividend), so it can be inferred the higher Dividend Payout Ratio set by the company's then increasingly higher amount of profit will be paid as a dividend on the share holders. Dividend Payout Ratio shows the company policy in generating and distributing dividends, Dividend Payout Ratio thus reflects the prosperity of the shareholders. The company's net income increases, then the company's ability to deliver dividends to investors will be much greater. Increasing the dividend given to shareholders, then the company's shares will be hunted by other investors, so will result in the company's stock price will rise.

Brigham and Houston (2010:134) mentions that the liquidity ratio is the ratio - which indicates the relationship between cash and other company assets liabilities with fluent lancarnya. This ratio indicator has some kind of ratio that each has its own goals and purpose. Current ratio is often used as a measure of liquidity, so this research use the current ratio to determine liquidity. This ratio indicates the extent to what current liabilities covered by assets expected to be converted to cash in the near future (Brigham and Houston, 2010:134). The high liquidity of a company is not necessarily good in terms of the profitability of the company, this is due to current high ratio can be caused presence of unbilled receivables or inventory unsold, which certainly alone cannot be used to pay debts. The condition of the company that owns the current ratio is considered good company and good, but if the current ratio is too high also considered not good because it can indicate an issue such as the amount of inventory will be relatively higher than estimates the level of sales so low inventory turnover rate.

\section{- PROBLEMS}

Based on the above background, which became a problem in this research is, "How does the influence of the Dividend Payout Ratio and Current Ratio posist more influenced and significantly to the growth of the share price in the period of service sector companies 2011 sd 2015. 


\section{REVIEW}

Library by Fahmi (2015:270) definition of the stock i.e. (a) proof of equity capital in a company/Fund; (b) a paper that stated clearly the nominal value, the name of the company and in the follow with rights and obligations are explained to each holder; (c) supplies are ready for sale. Widoatmodjo (2004:39) mentioned that the owner - is also the owner of a portion of the company, thus if an investor buys a stock, he became owner or shareholder of the company.

According to Darmaji (2001) in a Sari (2013), the stock is a sign of participation or the ownership of a person or entity within a corporation or limited liability company. The stock is the company's ownership proof letter that gives an income is not fixed. Stock owners would receive income in the form of dividends, and this dividend will be distributed to the shareholders if the company makes a profit. In addition to the income in the form of dividends, the profits expected from shareholders is the difference in share price (Sutrisno, 2013:104).

The types of Stocks according to Harjito and Martono (2013:40), namely:

\section{A. Preferred stock (Preferred Stock)}

Preferred shares (preferred stock) is a letter of equity (stocks) that have specific preferences (privileges) than common stock. These privileges, among others, regarding the payment of dividends and the Division of the wealth of the company if the company is liquidated (disbanded). Preferred stock usually entitles the owner to obtain a fixed dividend payment of percentage each year.

\section{B. Common shares (Common Stock)}

Common shares (common stock) is proof of ownership or evidence of the inclusion of a company that issued it (issuers). These issuers shaped limited liability company (PT). If the common shares bought traded to public (public) through the stock exchange, means the company that issued it already went public and the stock is already tedaftar (listing) on the stock exchange.

As preferred stock, common stock also gives the right to any dividend which has it. This dividend is payable by the issuer each year if the company is gaining profit. If issuers do not earn profits, then there is no dividend is paid or not. Nevertheless, although issuers obtain sometimes dividend not distributed to shareholders. This is because the profit will be used to reserve funds for the company. Reserve Fund from profit sharing will be used to develop the company.

\section{The factors that Affect Stock price movement}

According to Alwi in Wicaksono (2013) there are factors that affect the price of stocks, namely:

\section{A. Internal Factors (Micro)}

1. Announcements about marketing, production, sales as advertising, details of contract, price change, withdrawal of new products, production reports, security products, reports and sales reports.

2. Announcement of funding (financing announcements), such as announcements relating to equity and debt.

3. Announcement of the Agency's Board of Directors management (management-board of director announcements) as changes and changing of Directors, management, and organizational structure.

4. The announcement of the takeover diversified, such as mergers, equity investments report, reports take over by acquisition, and acquired other divestment reports.

5. The announcement of an investment (investment announcements), such as expanding the plant, research and development other business closing.

6. Announcement of employment (labour announcements), as negotiations for a new contract recently, strikes and other.

7. The announcement of the financial report of the company, such as forecasting earnings before the end of the fiscal year and after the end of the fiscal year, earning per share (EPS) and dividend per share (DPS), price earning ratio, net profit margin, return on assets (ROA), and others.

\section{B. External Factors (Macro-Environment)}

1. The announcement of the Government such as changes in interest rates on savings and deposits, foreign exchange rates, inflation, as well as regulation and deregulation of the economy released by the Government.

2. Announcement of the law (legal announcements), as the demands of the employees against the company or against her manager and demands the company against his Manager.

3. The announcement of the securities industry (securities announcement), such as annual meeting reports, insider trading, stock prices or the volume of trade, limitations/delays in trading.

4. domestic political Turmoil and fluctuations in exchange rates is also a factor that influence the occurrence of significant stock price movements on the stock exchange of the country.

5. Various issues both from within the country and abroad.

\section{$>$ Financial Ratios}

Financial ratios or financial ratio is very important to perform the analysis of the financial condition of the company. For short and medium-term investors are generally more interested in short term financial condition and company's ability to pay dividends. According to Warsidi (2015) is a financial ratio analysis instrument analysis company that describes the various relationships and financial indicators or operating achievements in the past and help illustrate the trend pattern of these changes, for 
then show the risks and opportunities inherent in the company concerned.

Financial ratios there are many in number and each has its usefulness ratio respectively. For investors he will see the ratio with the use of the best fits with the analysis that will he do. If the ratio is not the purpose of the present analysis is that will he do then the ratio is not used, because in the financial concept known by the name of flexibility, that is, formulas or different forms of the formulas used must be matched with the cases examined. In terms of financial experts that the market is the most good laboratories for testing and analysis capabilities, then all ownership formula and various thoughts that we have will be proven when we test on the market, such profit or rugikah will happen later (Fahmi, 2015).

\section{Types of financial ratios}

According to Harjito (2012) broadly speaking there are four (4) types of ratios that can be used to assess the financial performance of the company, namely:

- Ratio of Liquidity (Liquidity Ratio), i.e. the ratio which indicates the relationship between the company's cash and other current assets with debt well. The liquidity ratio is used to measure the company's ability to meet financial obligations that must be filled immediately or short term obligations.

- The ratio of Activity (Activity Ratio) or also known as the efficiency ratio, i.e. the ratio measures the company's efficiency in using its assets.

- Financial Leverage ratio (Financial Leverage Ratio) i.e. the ratio measures how many companies use debt funds (loan).

- The ratio of profit (Profitability Ratio) or earning ratios i.e. the ratio which indicates the company's ability to earn a profit from the use of its capital.

\section{$>$ Liquidity Ratio}

Hampton, mentions that the liquidity ratio-it aims to test the adequacy of the funds, the company's ability to pay immediate obligations to be met (Sugiono, 2009). According to Fahmi (2015:58) liquidity Ratio measures the company's ability to meet short-term obligations. This ratio is very important because failure in paying obligations could lead to the bankruptcy of the company.

Short-term creditors are always advised to focus his attention on the advantages of ordinary shareholders, but the focus of attention of the creditor is usually poured in another direction. Short-term creditors pay more attention to the prospects of the company in short term liabilities to pay. These creditors are more interested in cash flow and working capital management than how much profit the company reported accounting. In other words, the creditors are more interested in short-term liquidity of companies (Juliaty, and 2002:82 Prastowo). To measure this ability, researchers using the current ratio.

According to Harjito (2013), that the Current ratio is a comparison between current assets (current assets) and debts of smoothly (current liabilities). Aktivas smoothly consists of cash, securities, accounts receivable, and inventory. While debt smoothly consists of Payables, Payables Tax Payables, wesel, salary/wages, debt and other short-term debt. Current high ratio give an indication of the guarantee is good for short term creditors within the meaning of the company have the ability at any time to pay off financial obligations short term. But the current high ratio will effect negatively to obtain capabilities (earning ratios), because most of the working capital is not spinning or experiencing unemployment.

According to Brigham and Houston (2010) primary liquidity Ratio is the current ratio (current ratio) which is calculated by dividing assets seamlessly with current liabilities. This ratio indicates the extent to what current liabilities covered by assets expected to be converted to cash in the near future. According to Sugiono (2009), that the Current ratio is used to find out how far the company's current assets are used to pay off the debt (liabilities) smoothly which will be due/payable immediately. According to Subramanyam and John j. Wild in Fahmi (2015 reason uses current ratio (current ratio) is widely as a measure of liquidity include the ability to measure:

A. Capabilities meet current liabilities. Makin tinnggi number (multiples) of assets smoothly against current liabilities, the greater the confidence that current liabilities will be paid.

$B$. Buffer losses. The greater the risk is small, the pengangga. Current ratio indicates the level of security that is available to cover the drop in value of non-cash assets smoothly at the time such assets are discharged or dilikuiditasi. Ajanthan (2013) States - The dividend policy decision of firms are the primary element of corporate policy. Dividend, which is basically the benefit of shareholder in return for their risk and investment, is determined by different factors in an organization. ॥

Dividend policy is the decision as to whether the profit the company earned at the end of the year will be divided to shareholders in the form of dividends or will be withheld to increase capital in order to finance investment in the future. Dividend payout ratio (dividend payout ratio) to determine the amount of profit is shared in the form of cash dividends and profits on hold as funding sources. If the profit of the company who was arrested in large numbers, it means that the profit will be paid as a dividend to become small. Thus an important aspect of the policy dividend is determining the appropriate allocation of profits between the payment of profit as dividend with earnings withheld (Martono, 2013). The bigger profit was detained then fewer profit allocated for the payment of dividends. Determination of profit allocation as earnings withheld and the payment of dividends is a major aspect of the dividend policy.

Lintner in Horne and Wachowicz (1998) States that the dividend is adjusted to changes in earnings, but only with the slow movement. By the time the profit increase to a certain level, the company is increasing the dividend only if companies feel can maintain the profit increase. If the company has an excess of funds and there is not a profitable 
investment opportunities to allocate excess funds, then the company can distribute these funds for the benefit of shareholders. Distribution of the Fund can be made through the repurchase of shares or payment of dividends. Repurchase of shares, then the number of outstanding shares will decrease, so earnings per shares will rise and eventually the dividend per shares will also be increased, as a result the market price per shares will also increase. In theory, the capital gains derived from the repurchase of shares must be the same as the dividend payable.

\section{$>$ Dividend Forms}

According to Sugiono (2009), there is some form of dividends that will be distributed to the holders of ordinary shares, namely:

1. Dividends in cash (Cash Dividend), cash Dividends is a form of Division of dividends to shareholders in the form of cash (the cash). The Division of dividends in cash can be done periodically as per semester, per year and per quarter.

2. Dividend in the form of stock (Stock Dividend), the Dividend in the form of additional issuance of shares is stock to shareholders. This may occur if the financial position (cash position) insufficient or corporate companies want more pushing trade stocks by delaying its market price.

3. The breakdown of the price of the stock (Stock Split), it is different from the stock dividend, the stock split is to break the book value of the stock. Example: shares with nominal value of Rp. 500.00 will be conducted stock split 1:2, so that the nominal value of the shares will be USD 250.00. In the company's ownership percentage doesn't change, but the change happened just on the number of sheets that are owned by the shareholder concerned. It also aims to encourage a more liquid stock trading because the price will also drop.

\section{> Managerial considerations in Dividend Payments} According to Harjito and Martono (2013) there are some managerial considerations in dividend payments, among other things:

\section{- $\quad$ The needs of funds for the company}

The larger the company needs and means the less ability to pay dividends. The company's earnings will be used first to meet the needs of the Fund (all profitable investment project) new rest for the payment of dividends.

\section{- $\quad$ The company's Liquidity}

The liquidity of the company is one of the main considerations in policy dividends. Since the dividend is a cash flow out, then the greater the amount of available cash and liquidity of the company, the greater the company's ability to pay dividends. If the management wants to maintain liquidity in anticipation of the existence of uncertainty and in order to have financial flexibility, it's likely the company will not pay a dividend in large numbers.

\section{- $\quad$ The ability to borrow}

Liquidity position is not the only way to show flexibility and protection against uncertainty. If the company has a high ability to get loans, this is a high financial flexibility so that the ability to pay dividends is also high. If the company requires funding through debt, management does not need to be worrying about the influence of cash dividend against the liquidity of the company.

\section{- $\quad$ Limitations in the debt agreement}

Terms of protection (protective covenant) in a debt agreement often includes the limitation on payment of dividends. This restriction is used by lenders to maintain the ability of the company pay his debts. Typically, these restrictions are stated in the maximum percentage of the cumulative profit. When this restriction is made, then the management company may welcomes the restriction of dividends are subject to creditors, because thus the management don't have to guarantee his incarceration profit to shareholders. Management need only obey the restrictions.

\section{- $\quad$ The control of the company}

If a company pays huge dividends, then the company may raise capital in the future through the sale of its shares in order to finance the investment opportunities that are profitable. With the increase of the number of shares in circulation, there is the possibility of a group of shareholders that they've mastered being reduced from all outstanding shares. It is therefore considered harmful when the company too big to pay devidennya, thus controlling company into changing hands.

\section{$>$ Dividend Payout Ratio}

According to Rahardjo (2009), dividend payment Ratio (Dividend Payout Ratio) is a measure of the share of income paid in the form of dividends. This ratio is calculated by dividing dividends per sheet with the earnings per sheet for common stock (Rahardjo, 2009:82). The awarding of the dividend payout ratio is adequate will be one consideration of investors in buying and holding shares that it owns (Basir and Fakhruddin, 2005:94, Nurwani in 2013). Dividend payout ratio (dividend payout ratio) is the percentage of each dollar generated is divided to the owner in cash, calculated by dividing cash dividends per sheet with the earnings per shares (Sundjaja and Barlian, 2001).

According to Garrison and Noreen (2001:788) Dividend Payout Ratio measures the share of earnings is currently paid in the form of dividends. Investors who expect growth rates the market will prefer this small ratio while investors expect dividend would prefer if this large ratio this ratio shows the percentage of corporate profits paid to shareholders in the form of cash.

\section{RESEARCH METHODS}

The place of research, namely the automotive companies listed on the Indonesia stock exchange (idx) of the period 2011-2015, and the scope of the research in the financial reports is BEI meets a criterion variable and fixed research published during the year observations (20112015). Which became population in this peneltian is the entire service sector companies were listed on the Indonesia 
stock exchange period 2011 - 2015 totalling 198 fruit company.

The sampling techniques used in this research is purposive sampling method. In this study data used are secondary data.

Data collection techniques used in this research is the technique of documentation data analysis techniques used in this research is the regression analysis of the data panel. Panel data regression analysis regression is a combination of a periodic time data (Time Series) Data and the Crossection test causal relationships among variables with variables bound. This research did the panel data regression by testing the influence of Current Ratio and Dividend Payout Ratio against the Automotive Company stock price listed on the Indonesia stock exchange (idx) of the period of 2011-2015.

Multiple linear regression formula that the equation can be written as follows:

$\mathrm{Y}=\alpha+\mathrm{b} 1 \times 1+\mathrm{b} 2 \mathrm{X} 2+\mathrm{e}$

$y=$ growth of stock price

$\alpha=$ constant

$\mathrm{B} 1, \mathrm{~b} 2$ = a coefficient

x 1, x 2 = variable

$\varepsilon=$ equivalent

\section{A. Hypothesis Testing}

Hypothesis testing in this study using a test tool that is include; partial test (t-test), simultaneous test (f-test), and test the koefeisen determination (R2).

\section{B. $\quad$ Test T(Partial Test)}

According to Ghozali (2011) in the main (2014) test statistic $t$ is used to indicate how far the influence of one independent variable, individually, in explaining the variation of the dependent variable. T-test was conducted to test the influence of free variables $(\mathrm{X})$ against variable $(\mathrm{Y})$ is partial. Testing against test performed using the regression results $t$ on the degree of confidence of $95 \%$ or $\alpha=5 \%$ (cider, 2013). When the level of significance (Sig t) smaller than $\alpha=0.05$, then the $\mathrm{H} 1$ is accepted which means independent variable in the partial effect significantly to the dependent variable. Vice versa if significant $t$ greater than $\alpha$ $=0.05$, then $\mathrm{H} 1$ denied that it means partially independent variables do not affect the dependent variable significantly to.

\section{F-Test (Test of Simultaneous)}

The F-test is used to test the influence of the free variable $(\mathrm{X})$ against variables bound $(\mathrm{Y})$ simultaneously. Error rate in this study by 5\%. When the level of significance (Sig f) smaller than $\alpha=0.05$, then the H1 is accepted which means independent variable simultaneously effect significantly to the dependent variable. Conversely, if sig $\mathrm{f}$ is greater than $\alpha=0.05$, then $\mathrm{H} 1$ denied which means simultaneous independent variables do not affect the dependent variable significantly to.

\section{The Coefficient of Determination (R2)}

Wicaksono (2013) value of R2 aims to find out how big the ability of free variables describes variables are bound. In other words, the coefficient of determination is used to see how big the influence of independent variables or in explaining the overall against the dependent variable or attached, as well as its influence is potentially known from the magnitude of the value of the coefficient of determination (R2) formulated with: $\Sigma(\mathrm{Y}-\mathrm{Y}) 2=1-\mathrm{R} 2 \Sigma$ $(\mathrm{Y}-\mathrm{Y}) 2$.

\section{$>\quad$ The Results o the Research and the Discussion}

\section{A. Hypothesis Testing}

After testing as a whole performed, further testing was done partially to know the influence of the value of current ratio and the value of the dividend payout ratio against the stock price. For the purposes of testing the regression coefficient was done individually (Individual Regression Testing Coefisient) using t-test. If the absolute value of the $\mathrm{t}$-count obtained is greater than the value of the t-table at the level of particular significance and non-degree (NT-N-k) then $\mathrm{HO}$ is rejected. Determination of the test criteria is based on a comparison between the t-value is obtained by calculating the t-table. If the value is t-count greater than $\mathrm{t}$ table then $\mathrm{H} 0$ is rejected, and if the value is t-count is less than the value of the t-table then $\mathrm{HO}$ are received. The determination of the criteria of the test can also be done by comparing the value of significance for the t-value is obtained by calculating the alpha was used. If the value is smaller than the value of significance alpha then $\mathrm{HO}$ is rejected, and if its significance is greater than the value of the alpha then $\mathrm{H} 0$ are received.

\section{B. The Results of The Regression Analysis}

After the classical assumption requirements are met then the next conducted regression analysis to see the influence of the value of the current ratio and the value of the dividend payout ratio against the company's share price the service sector. Because the data is analyzed in the form of pooled data (a combination of a cross section data/industrial companies with similar data with time series/year) then the regression analysis used is stock price $=$ $5423.52-13.567(\mathrm{CR})+19.509(\mathrm{DPR})+\varepsilon$

\section{The Test of Hypothesis}

To get the conclusion whether accept or reject H0, must first be determined value of the t-table to be used. By using the level of significance of $5 \%$ and the value of df $t$ value obtained 22-table of 2.074. Results of testing the influence of each variable non-Current Ratio (CR) and the Dividend Payout Ratio (DPR) against variables bound i.e. the share price on the service sector Companies were listed on the Indonesia stock exchange (idx) is as follows:

- Current Ratio Influence against the growth of stock price 
From the results of the analysis have been made known to the absolute value of the t-count to a variable Current Ratio is of significance to the value of 3.1250 .0049 . If the value of this significance compared to the alpha value used $(0.05)$ then the significance value obtained is still smaller than the alpha value so that $\mathrm{HO}$ is rejected. Similarly, if you use a comparison between the value of the count of $t$-and $t-$ table where the value of a t-chart on the level of significance of $5 \%$ and non-degree of 22 is 2.074 . When compared with count of t-values-3.125 then t-count obtained is still bigger than the t-table so that $\mathrm{H} 0$ is rejected. Thus it can be concluded that the Current value of the Ratio that is owned by the influential company share price significantly to service sector companies during the years 2011-2015.

\section{- $\quad$ The influence of the Dividend Payout Ratio against the growth of stock price}

From the results of the analysis have been made known to the absolute value of the $\mathrm{t}$-count to a variable Dividend Payout Ratio is of significance to the value of 2.5350 .0189 . If the value of this significance compared to the alpha value used (0.05) then the significance value obtained is still smaller than the alpha value so that $\mathrm{H} 0$ is rejected. Similarly, if you use a comparison between the value of the count of tand t-table where the value of a $t$-chart on the level of significance of $5 \%$ and non-degree of 22 is 2.074 . When compared to the t-value is the count of 2.535 then $t$-count obtained is still bigger than the t-table so that $\mathrm{HO}$ is rejected. Thus it can be concluded that the value of the Dividend Payout Ratio which is owned by the influential company share price significantly to service sector companies during the years 2011-2015.

\section{F-test (simultaneous)}

Based on the above analysis of the obtained results table value of 9.45-female F-value significance of 0.000021 . As for the F-value table on a confidence level of $95 \%$ and df1 and df $2=6=22$ is amounted to 2.55 . F-value table is much smaller compared to the F-value calculate obtained so that $\mathrm{H} 0$ is rejected. Similarly, if you use the value of the acquired significance is still smaller than the alpha value $(5 \%)$ sehinggan $\mathrm{HO}$ is rejected. Thus it can be concluded that all the regression coefficients are significant. In other words, variable current ratio and dividend payout ratio together influential significantly to service sector companies stock prices during the years 2011-2015.

\section{E. Coefficient of Determination}

Based on the results of the analysis that has been done previously known that the determination of the coefficient values for the regression model is observed of 0.7504 . This means that the value of $75.04 \%$ change in the price of shares of the company's service sector is observed during the year 2011-2015 is affected by the value of the current ratio and the value of the dividend payout ratio of company-owned, while the rest of $24.96 \%$ affected by other variables.

\section{DISCUSSION}

Of Stock investment instruments is one that is able to provide a return above the higher deposits. The source of the return on investment of shares derived from capital gains and dividends. Return comes from capital gains largely determined by the price movement of stocks in the market. While the market price is determined by market mechanisms, namely the power of supply and demand a stake in capital markets. Increased interest of investors to have a stock is affected by the quality or value of shares in the capital market. High low value stocks actually reflected on the financial performance of the company. If a company has a good financial performance then investors will infuse capital, because it is certain it will benefit from the investment.

Many of the indicators used in the analysis of the performance of the company including the company's liquidity. Liquidity analysis is one factor that could push the stock price changes. High liquidity shows the company's ability to meet short-term obligations. The liquidity of the company can be measured by some ratio including current ratio (current ratio). Current ratio indicates the company's ability to pay debts smoothly by using current assets that are owned. Current ratio (current ratio) is usually used as a tool to measure the State of the liquidity of a company, and also the instructions to be able to know and suspect to where we may, when giving credit to short futures to a client, can feel safe or not.

Based on the results of the research on the corporate sector experiencing fluctuating period of 2011-2015 services, with the highest ratio of current value $212.99 \%$ in 2011 and the value of the current lowest ratio amounted to $149.49 \%$ in 2012. telecommunications increase and decrease in 2011-2015, this is caused by the company which is engaged in a variety of policies that promoted the restructuring of corporate profit. Unlike with other service companies such as restaurant, Brasserie and hospitality that is experiencing an increase exceeding the standards set forth in his book Harjito and Martono, 2013:56, the magnitude of the current ratio of about $200 \%$ is considered good. This is caused by too high a current assets while the debt that must be repaid is too low. According to Fahmi, the 2005:118, the company that owns the high liquidity ratio will be attractive to investors and will also affect the stock price tends to rise because of the high demand. But it said Weaver and Weston dalma book Fahmi 2015:69, that the current ratio value is ektrem can indicate an issue, such as: 1) hoarding cash; 2) the large number of unbilled receivables; 3) buildup of inventories; 4) not efisiennya utilization of financing; 5) low short term loans. It is proven by testing the hypothesis.

The first hypothesis test results found that the value of t-count greater than the value of the t-table. So it can be said to be the current ratio effect significantly to the growth of the service sector Companies stock prices listed on the Indonesia stock exchange. As for the influence of great current ratio against the stock price of the company's services sector i.e. $3.125 \%$. The results of the regression coefficients were negative indicated that when the value of current ratio the more riding then its impact on the value of the service sector Companies stock prices listed on the Indonesia Stock Exchange will progressively decrease. Significance the results of this showed that investors are 
doing an assessment on the financial performance of companies in particular levels of liquidity. So it's important for companies to keep the current ratio is standard i.e. 2:1. It is so that there are no circumstances where the company could not afford to pay off short-term debt.

Assets smoothly considerable value which in this case is used as the numerator in the calculation of current ratio could have been dominated by the unbilled receivables components and supplies that have not sold the value of both these components more from high on the value of the component assets smoothly other used to pay debts. If this happens, the current ratio of a company will be high and resulted in the company as if it were a liquid condition daam. Overall it can be said that the results of the research there were namely negative influences and significantly to the price of shares in the company sector services. These results are inconsistent with penilitian Meythi, et al (2011) with liquidity and profitability of the influence of title Against the growth of stock price manufacturing companies registered in BEI. The results of his research shows partially current ratio does not have a significant impact on the stock price, because the value of their significance over the value of alpha i.e. 0.650. The difference i.e. research Meythi, et al

\section{$>$ The Influence of the Dividend Payout Ratio Against the Growth of Stock Price}

In addition to liquidity factors, there are other factors that also often noticed by investors in conducting analysis of a stock dividend policy the company IE. Dividend is the distribution of profits to holders of equity investments with their proportion of the type specific capital. Dividend is the Division of profit the company that the magnitude of the AGM to shareholders proportionately in accordance with the number of shares owned by each shareholder. To measure his little big dividends that investors receive in use indicator Dividend Payout Ratio (DPR). This ratio is the percentage of the profit the company paid cash dividends to shareholders. Dividend Payout Ratio shows the magnitude of the earnings will be paid out to shareholders in the form of dividends.

Results of the study showed that the highest dividend payout ratio value of $78.78 \%$ in 2011 and the value of the lowest dividend payout ratio amounted to $29.01 \%$ in 2015 . This is caused by the ups and downs of company earnings and the decision in the GENERAL MEETING OF SHAREHOLDERS are profits generated will be shared or made a profit was arrested for funding in the future. also expanding from the beginning 2012 up to mid-2014 with an investment value of $\$ 39$ million.

As it was said though Halim (2003:17) that the decline in dividend payout - (dividend payout) considered the prospect of a less good profit levels, finally cederung followed the stock price up and down the magnitude of the dividend is paid. The results of the analysis that has been done shows that the value of the Dividend Payout Ratio providing a positive influence against the stock price. In other words, if the value of the Dividend Payout Ratio the company experienced an increase in the price of stocks will also experience increased. Dividend Payout Ratio is a ratio that measures the comparative profit dividend against the company. Policy dividend could also be linked to the value of the company. With the Dividend Payout Ratio is lower will maximise the value of the company, the payment of dividends is often followed by the stock price. Cash dividend can increase the company's value because through the announcement of dividends, managers can deliver news to the investors that the company has availability of funds to finance its activities. So the reaction that occurs is the stock price increases.

These results are in accordance with the concept that States that an increase in the Dividend Payout Ratio shows an increase in the company's performance, with an increase in the company's performance then it will make investors more confidence that it will be influential against an increase in the stock price. This is in line with the research Rohmawati (2017) Influence the Volume of sales, Dividend Payout Ratio and inflation Against the volatility of stock prices in the companies listed in the index of LQ45 Years 2011-2015. The results of the research show that the dividend payout ratio is positive and significant effect against the volatility of the stock price to the value of the coefficient of 0.016482 and its significance level smaller than the alpha i.e. of 0.0135 . Although in the year 2013 the high inflation that is occurring of 0.0697 , however the increase in dividend payout ratio was still followed by a rise in stock prices. A company's value would be maximized by a cash dividend payout ratio is high then in this research has proved that the Division of dividends can affect or increase the price of a stock of a company. The content of the information or the persinyalan contained in the announcement of the dividend will give a signal for investors about changes in stock prices, it is evident that the information pertaining to dividends will be positively responded by investors so that can boost stock prices. the average value of the stock price service companies rose on the year 2012 is Rp. 326, and in 2013, 2014, and 2015 are likely to decline. This condition can affect the level of investor confidence as well as potential investors in the company, because if the return on stocks rising, it will be an attraction for investors to infuse capital, as well as vice versa.

\section{CONCLUSION}

Based on the results of research and discussion in the previous chapter, it can be drawn some conclusions here partially, the value of the current ratio of negative and significant effect against the growth of the service sector of the company's stock price during the past year 2011-2015, evidenced by the t-value is the count of greater than $3.125 \mathrm{t}$ table of significance and value of 2.0750 .0049 smaller than 0.05 alpha. Partially, the value of the dividend payout ratio is positive and significant effect against the company's share price the service sector during the year 2011-2015, evidenced by the $t$-value is the count of 2.535 bigger than $t-$ table of significance and value of 2.0750 .0189 smaller than 0.05 alpha. Overall, the value of the current ratio and dividend payout ratio significantly influential towards the service sector company's share price during the year 2011- 
2015, evidenced by the F-value of 9.45 count greater than Ftable 2.55 and value significance of 0.000021 smaller than 0.05 alpha. with the determination of the coefficient of $75.04 \%$, while the rest of $24.96 \%$ influenced by other variables.

\section{BIBLIOGRAPHY}

[1]. Ajanthan. 2013. The Relationship Between Dividend Payout and Firm Profitability: A Study of Listed Hotels and Restaurant Companies in Sri Lanka. International Journal of Scientific and Research Publications, Volume 3, Issue 6, June 2013, ISSN 2250-3153.

[2]. Alannurfitrah. 2012. The movement of stock prices and factors that affected it. [Online] Available: Html https://shareshareilmu.wordpress.com [April 14, 2012].

[3]. Aminatuzzahra. 2010. The analysis of the influence of Current Ratio, Debt to Equity Ratio, Total Asset Turnover, Net Profit Margin Against ROE (case study on the Go-Public manufacturing company in BEI 20052009 Period). Thesis: University Of Diponegoro, Semarang.

[4]. Arifin, Ali. 2007. Reading Art basic guide to Stock investing. Yogyakarta: Cv. Andi Offset. Ayuningtias, Dwi and the gift. 2013. The influence of the Profitability Of the company and the Dividend Policy: Investment Opportunity as variables Among. Journal of Accounting Research and Science. Vol 1 No 1 thing 37-57.

[5]. Bagherzadeh, et al. 2013. the Relationship between Current Ratio and the Share Price - a study on NSE, INDIA (2009-2012). Int Jr. Of Mathematical Sciences \& Applications vol. 3, no. 1, January-June 2013.

[6]. Brigham and Houston. 2010. The basics of financial management. Salemba Jakarta: Four.

[7]. Fahmi, Irham. 2015. Risk management theory, cases, and solutions. Bandung: Alfabeta.

[8]. Fahmi, Irham. 2015. Introduction to financial management theory and the question of responsibility. Bandung: Alfabeta.

[9]. Garrison and Noreen. 2001. Managerial Accounting. Salemba Jakarta: Four. Gujarati, Damodar. 2005. Basic Econometrics. Translation: Sumarno Zain. Jakarta: Eason.

[10]. Halim, Abdul. 2003. Investment analysis. Salemba Jakarta:

Four.

Hantono. 2016. The influence of size of companies, Total Debt, Current Ratio Against the financial performance and stock price as a Moderating Variable. Journal Of Economic Mikroskil Hero. Vol 6 No 01 April 2016

University Of Indonesia Prima.

[11]. Harjito, Agus and Martono. 2013. The second issue of financial management. Yogyakarta: Ekosiana. Horne,

[12]. J.C.V. and Wachowicz, John. M. 1998. The principles of the financial

management of the Ninth Edition. Jakarta. Salemba Empat.

Hunjra, a. i., et al. 2014. The Impact of Dividend Polic, Earning per Share, Return on Equity, Profit After Tax on Stock Price. International Jounal of Economics and Empirical Research. 2 (3), 109-115.

[13]. Pakistan.Istanti, s. 1. w. 2013. The influence of Policy Dividends on the company's share price against the LQ 45. Journal. Vol 19 No 1. STIE YPPI, Rembang.

[14]. Jogiyanto. 2003. The Portfolio Theory and investment analysis. Yogyakarta: BPFE-UGN.

[15]. Cashmere. 2008. analysis of financial statements. Jakarta: PT Raja Grafindo Persada.

[16]. Keown, Arthtur J, et al. 2000. The basics of financial management. Salemba Jakarta: Four.

[17]. Makridakis, et al. 1983. Forecasting Methods and Application. Jhon Wiley \&amp; Son. New York.

[18]. Meythi, et al. 2011. The influence of Liquidity and profitability Against stock price manufacturing companies listed on the Indonesia stock exchange. Journal of business management and economics. Vol 10 No 2.

[19]. Nurwani, Ayu Dinar, et al. 2013. The influence of the Bid-Ask Spread, Market Value, Risk Of Return, and the Dividend Payout Ratio against the Holding Period of common stock. Journal. University Of Brawijaya

[20]. Prastowo, Dwi and Juliaty, Rifka. 2008. analysis of financial statement concepts and Applications Second Edition. Yogyakarta: YKPN.

[21]. Budi Rahardjo,. 2009. The company's financial reports. Yogyakarta: Gadjah Mada University Press.

[22]. Rohmawati, Irma. 2017. influence trading Volume, Dividend Payout Ratio and inflation Against the volatility of stock prices in the companies listed in the index of LQ45 Years 2011-2015. Journal of education and the economy, Vol 6 No 01. State University Of Yogyakarta

[23]. Sari, Eling. Monika. 2013. The analysis of the influence of Current Ratio, Return On Assets, Debt to Equity Ratio, and Size Towards the stock Return on manufacturing companies listed on the Indonesia stock exchange Period 2008-2011. Thesis: State University Of Yogyakarta.

[24]. Setiyawan, Indra. 2014. The influence of Current Ratio, Inventory Turnover, Time Interest Earned and the Return on Equity Against the share price in the Sector of consumer goods manufacturing company listed in BEI 2009-2012 Period. Nominal Journal Vol III No. 2 the year 2014. State University Of Yogyakarta.

[25]. Sidabutar, Chrytine. 2012. The influence of Current Ratio (CR), Debt to equity Ratio (DER) and Return On Equity (ROE) of stock prices at the manufacturing companies of the food industry and beverages are listed on the Indonesia stock exchange. Thesis: University Of North Sumatera, Medan.

[26]. Sugiono, Arief. 2009. Financial management to Financial Practitioners. Jakarta: Grasindo PT.

[27]. Sulistyowaty, Yayuk. 2012. The influence of Earning Per Share (EPS), Price Earning Ratio (PER), and the Dividend Payout Ratio (DPR) Against the stock price on the company Food Beverages \& registered in BEI. Journal. Vol 8 No 3. 
[28]. Sundjaja, r. s. and Barlian, Inge. 2001. Two financial management Second Edition. Jakarta: PT Prenhallindo.

[29]. Sundjaja, r. s. and Barlian, Inge. 2003. Two financial management Fourth Edition. Jakarta: Literata Cross-Media.

[30]. Sutrisno. 2013. The theory of financial management Concepts \& application. Yogyakarta: Ekosiana.

[31]. The Main, Alfarizi. Michael Horn. 2014. The influence of Current Ratio, Debt Equity Ratio, Debt Ratio, Asset and working capital Turnover against the Return On Assets on the manufacturing companies listed on the Indonesia stock exchange Years 20102012. Thesis: University Of Diponegoro, Semarang.

[32]. Wicaksono, Hendra Adhitya. 2013. The influence of Current Ratio, Debt to Asset Ratio, Total Asset Turnover, Return On Equity, interest rates, Foreign Exchange Rates, inflation, and cash Dividends Against share price food and beverage companies that are registered in BEI 2009-2011 Period. Thesis: State University Of Yogyakarta.

[33]. Widoatmodjo, Sawidji. 2004. How Fast a stock Investment Guide for beginners. Jakarta: PT Elex Media Komputindo. 